\title{
Unemployment and Access to Health Care
}

1 Boris llić

1 Sanja Ledinski Fičko

1 Ana Marija Hošnjak

1 Irena Kovačević

1 Martina Smrekar

1 Biserka Sedić

1 University of Applied Health Sciences, Zagreb, Croatia

Article received: 04.06.2019.

Article accepted: 21.11.2019.

DOI: $10.24141 / 2 / 3 / 2 / 6$

Author for correspondence:

Boris llić

University of Applied Health Sciences

Mlinarska 38, Zagreb, Croatia

E-mail: boris.ilic@zvu.hr

Keywords: unemployment, health care, economic crisis, recession

\section{Abstract}

Introduction. At the time of the global economies' recovery from the effects of fourth major recession after the Second World War, there was a major increase in the unemployment rate that created a significant existential and public health challenge.

Aim. The aim of this study was to provide a systematic review of available research on effects of unemployment on access to health care, and consequentially on health of the population.

Methods. A systematic search of relevant, peer-reviewed electronic databases was conducted to identify systematic reviews, review articles, original research papers and reports for the period of past ten years.

Results. 10.234 results were initially identified, five of which were included in this review.

Conclusion. Significant number of studies confirms that the unemployed individuals, due to sometimes limited access to health care, have impaired health in comparison to the employed population, both in physical and mental health. Global economic change will have a stronger impact on the health of the population in poor countries, therefore a fair and comprehensive system of health care for the unemployed is of paramount importance for the purpose of preserving the health of the population. 


\section{Introduction}

The consequences of the fourth global economic recession, according to the International Monetary Fund, the worst since Second World War in terms of overall impact (1); have left high unemployment rates and pose a significant public health challenge to many countries in the world. In addition to the consequent threat to the health system and access to health care, global economies have remained significantly disrupted. The Gross Domestic Product (GDP) average in the Eurozone fell sharply from $0.7 \%$ in 2008 to $-4.1 \%$ in 2009 , while the U.S. and world economies followed this trend (Chart 1 ).

\section{Unemployment growth as a result of the crisis}

According to International Labor Organization (ILO) projections, nearly 20 million jobs in the world were lost by the end of 2009, as a direct consequence of the crisis, bringing the number of unemployed in the world to over 200 million for the first time (2). An additional 5 million people were in direct risk of losing their jobs as a result of reduced working hours, part-time employment and the transition to part-time employment.

The unemployment rate in the United States has increased from $4.9 \%$ in 2007 (3) to $10.1 \%$ by 2009 (4). Member States of the European Union have also followed negative trends in employment decline. Ac- cording to Eurostat, Spain was most affected by the crisis, where unemployment reached $17.9 \%$ in 2009 (5). In Croatia, it was $9.2 \%$ in 2009 , representing an increase of $0.6 \%$ compared to the previous year.

The largest increase in unemployment was recorded in the construction, financial, automotive and real estate markets. Two thirds of the countries covered by the 2009 ILO report, do not pay unemployment benefits (2).

\section{Impact of the macroeconomic stability on population health}

By disrupting the macroeconomic stability of countries and consequently reducing the supply of jobs in the labor market, a significant number of people who lost their jobs in the post-recession period ultimately depended on the social measures of the state when it comes to health care and access to it. The share of GDP earmarked for social care programs and the health system in general decreases, which ultimately, depending on the health system, potentially leads to impaired health quality, impaired mental health (1), increased levels of stress, avoidance in seeking medical care, difficult access to medicines, lack of preventive measures and many other adverse health effects.

\section{Health insurance of the unemployed}

In most cases, unemployed citizens are dependent on health insurance mainly financed by the state (i.e. taxpayers), introduced with the aim of preserving

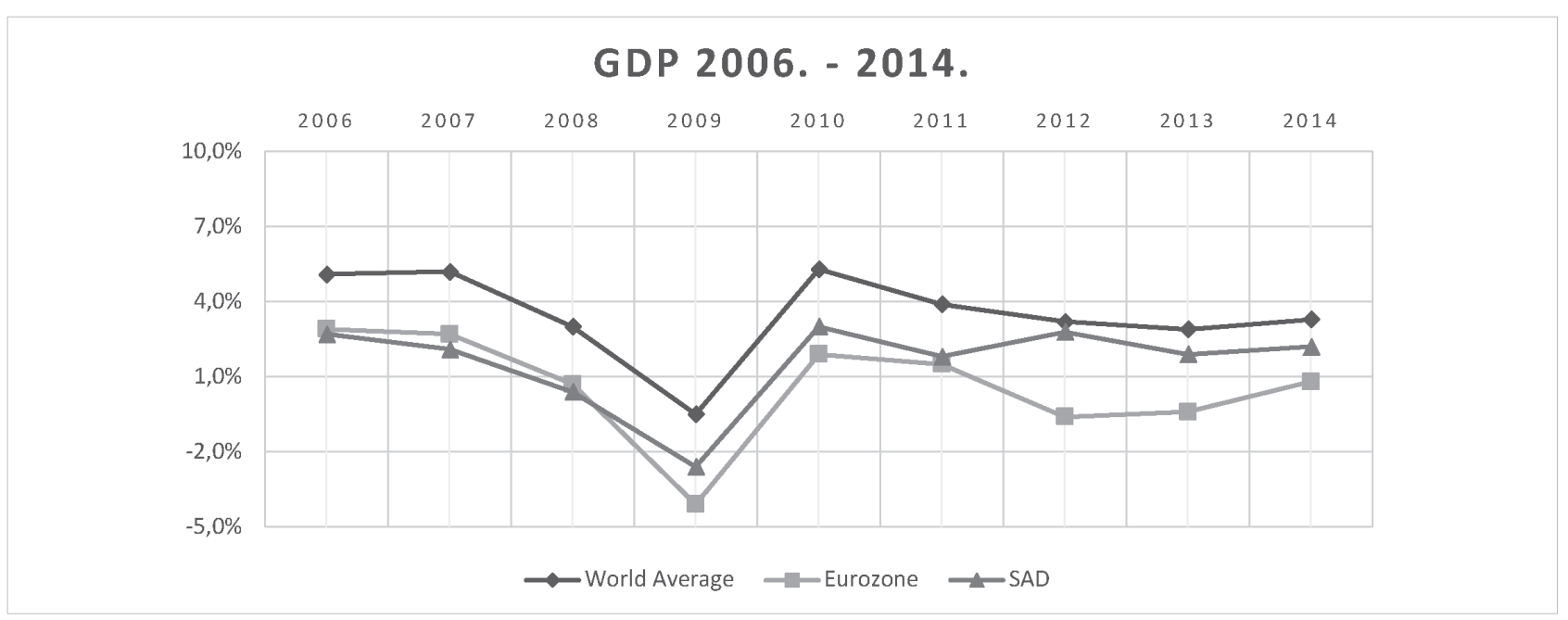

Chart 1. Outline of GDP trends from 2006 to 2014 (\%) 
the health of the individual in situations when loss of regular income occurs. Such insurance systems vary significantly between countries, and sometimes between provinces within countries $(6,7)$. The aforementioned differences include sources of financing (workers, state, employers), additional criteria (loss of work not caused by workers), duration of insurance, grace period (time during which insurance is not paid) (8). In the Republic of Croatia, the rights of the unemployed to basic health insurance is regulated by Article 7 of the Act on Mandatory Health Insurance NN83/13, 137/13. Available studies have shown that countries with developed unemployment insurance systems are extremely successful in eliminating the financial burden of unemployed citizens, protecting them from severe material losses, and ultimately preventing poverty rates from rising. Comprehensive social protection measures for citizens are particularly important in times of difficult economic circumstances given the increased unemployment and risk of job loss.

\section{Methods}

\section{Selection criteria and search terms}

A systematic search of the electronic databases Science Direct, PubMed and Scopus was performed, searching for articles from 2008 to 2018 . This criteria was decided due to the different beginning of the financial crisis in the countries of the world.

The articles with available abstracts in Croatian and English are discussed. Part of the keywords were identified using the MeSH database and these were: "unemployment", "health services accessibility", "healthcare". Subsequent searches searched for the terms: "health insurance macroeconomy" and "recession". In order to ensure the representation of all relevant research, the references of selected articles were further searched and included in this paper based on the inclusion criteria (Table 1). Article summaries whose eligibility could not be concluded were subsequently analyzed by reviewing the entire paper.

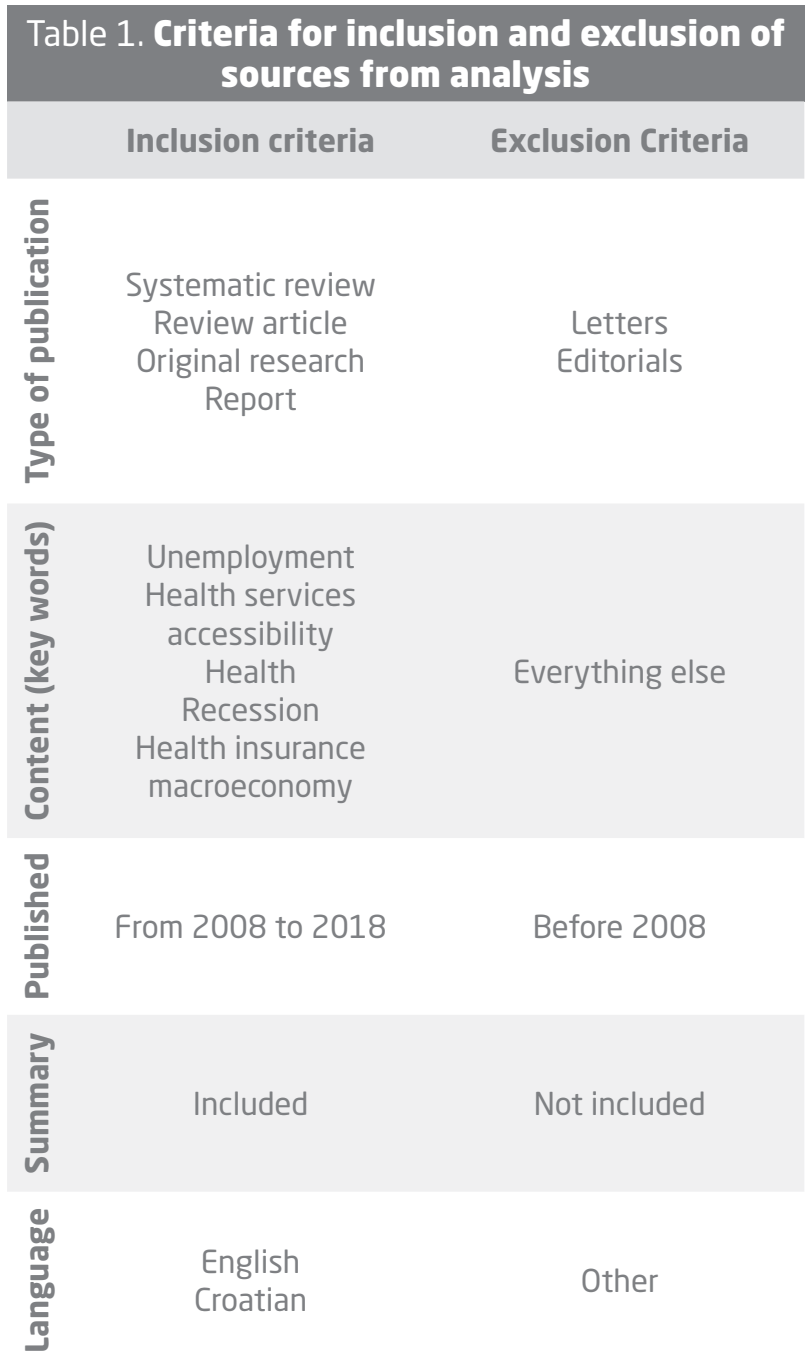

\section{Refinement and selection of the studies}

Based on keyword searches in the databases, a total of 10234 papers were found. The initial review excluded duplicates and papers according to the criteria, selecting 82 papers for further review. After reviewing the abstracts, 54 papers were excluded, 28 whole papers were reviewed, five of which were included in this review. 


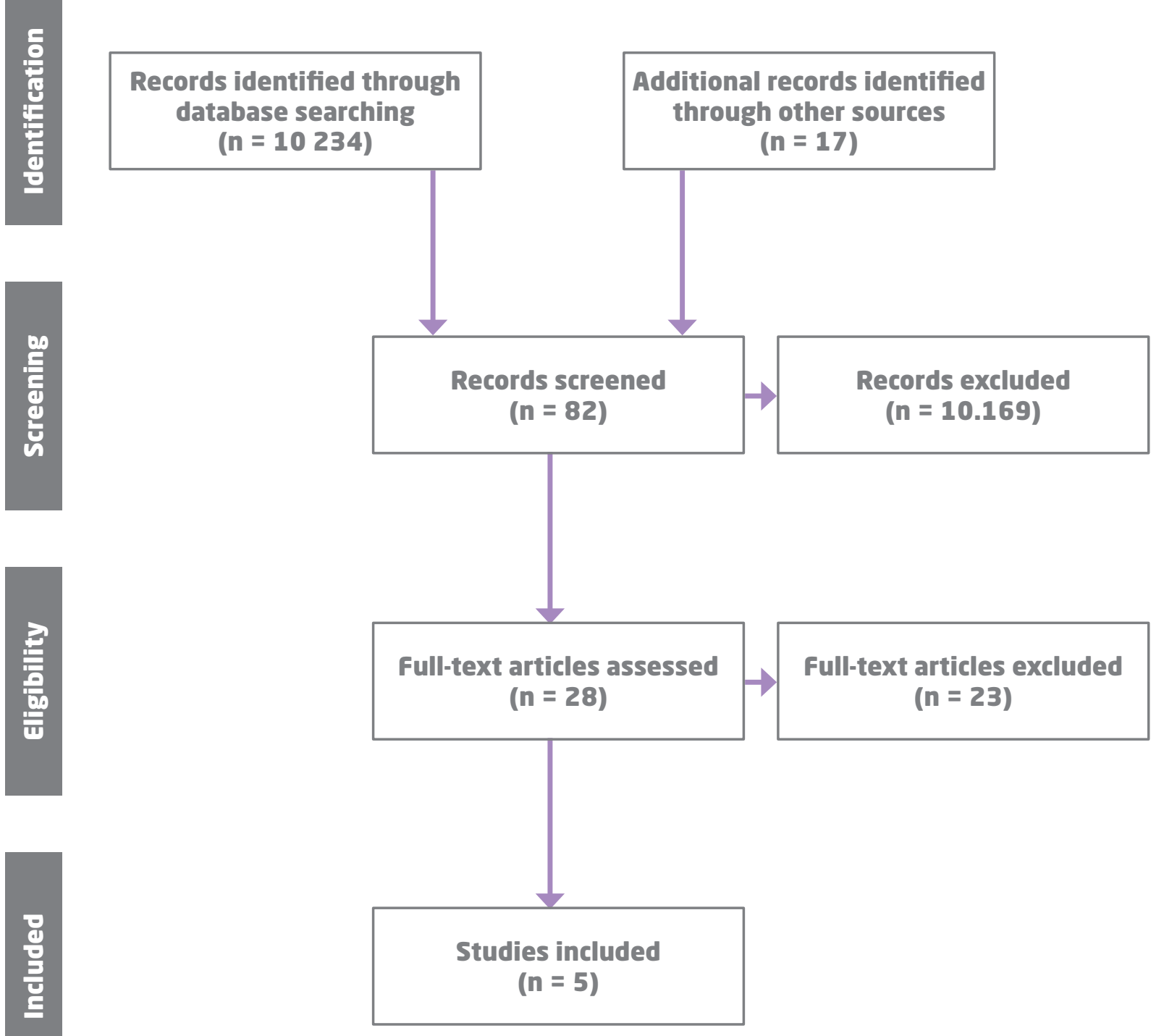

Diagram 1. Selection process of the studies. Prisma 2009 Flow Diagram

\section{Results}

Driscoll and Bernstein (2012) made an analysis based on the data from the National Health Survey 2009/2010, which was conducted in the United States. The aim of the analysis was to compare and identify possible differences in access to health care between employed and unemployed adults, aged 18-64. The results were collected through household interviews, continuously throughout the year. Given the organization of the health care system in the United States and the lack of a social component of the health care system, unlike the countries in Europe or Canada, most U.S. citizens rely on employerprovided health insurance. It is for this reason that accessibility to health care services is significantly hampered by the loss of jobs and income that citizens could use to pay for insurance themselves (9).

Drydakis (2015) conducted a longitudinal study before and after the financial crisis, aiming to discover 
the impact of unemployment on self-assessment of health and mental health in Greece for the period between 2008 and 2013. An analysis of data from 2008-2009 and 2010-2013 examined the extent to which unemployment had an impact on health and mental health, at a time when unemployment in Greece had doubled as a result of the economic crisis. The paper tested and validated two hypotheses: a) unemployment can result in worse health, and b) during 2010-2013, unemployment resulted in greater impairment of health compared to 2008-2009 (10).

Pharr et al. (2012) conducted a secondary analysis of data collected from the BRFSS (Behavioral Risk Factor Surveillance System) of the State of Nevada, USA. Data were collected by telephone survey on 3,840 respondents over 18 years of age. The aim of the study was to examine the impact of duration and length of unemployment on health self-assessment, access to health care, and risky health behaviors (11).

Noordt et al. (2014), through a systematic analysis of prospective studies, sought to explore the impact of employment on an individual's health. By searching the scientific databases (Medline, PsychINFO, SciSearch, Social SciSearch and EMBASE) they included 33 studies, of which 23 were rated as qualitative. The search was limited to the period from 1990 to March 2012 (12).

Bambra and Eikemo (2008) wanted to establish a link between unemployment and an increased risk of morbidity and mortality with different levels of social protection for the unemployed. As the source, 37499 respondents were used on two occasions, in 2002 and 2004. The data for 23 European countries was presented through five models of social protection: Scandinavian (universal health care, promoting social equality not to the minimum but the highest standards of protection), Bismarck's (status-organized programs where the level of social protection is often determined by earnings), Anglo-Saxon (state influence in social programs is minimal, level of protection modest and recipients are often stigmatized), Southern (rudimentary, fragmented systems with limited and partial coverage of services), Eastern (former Eastern European countries, change from universal health care to modified Anglo-Saxon) (13).

\section{The impact of unemployment on health self-assessment}

Driscoll and Bernstein (2012) found that $11.3 \%$ of unemployed adults in the United States, aged 1864 , rated their health poor or bad, compared to $5.3 \%$ of employed participants. In the population of respondents with private insurance (self-paid), 4.3\% of employees assessed their health as impaired and poor, as opposed to $7.8 \%$ of the unemployed - which confirms the negative impact of unemployment on health despite the possibly better health insurance. Respondents with social (state) insurance rated their health as poor, regardless of the employment (9).

Drydakis (2015) evaluated the positive relationship between unemployment and impaired health, that is, the negative effect of unemployment on health by $0.18 \%$, thus accepting the hypothesis that unemployment results in worse health (10).

Bambra and Ekimo (2009) found greater relative inequalities in the countries of Anglo-Saxon, Bismark (male only) and Scandinavian (female only) health care models, while the least inequalities were reported in Southern (Italy, Portugal, Spain, Czech Republic) and Eastern (Hungary, Poland, Slovenia) Europe (13).

\section{The effects of unemployment on the mental health of an individual}

Unemployed participants reported a greater amount of significant psychological distress (6.3\%), as opposed to employed participants $(1.7 \%)$, regardless of the level or source of health insurance. Unemployed respondents with private health insurance were three times more likely to have more serious psychological consequences than employed participants. Respondents with social (state) insurance had more serious psychological consequences, regardless of employment (9).

At the individual level, studies have shown a link between poorer mental health assessments, including parasuicide, and a higher prevalence of risky health behaviors in terms of smoking and alcohol consumption, especially in the younger male population. At the national level, an increase in the unemployment rate is associated with higher mortality (13).

People who have been unemployed for less than a year are more likely to assess their mental state as worse than the employed respondents, as well as a significantly larger number of days when they ex- 
perience impaired mental health. Respondents who have been unemployed for more than a year have assessed their mental state significantly worse than the employed ones. Other statistically significant indicators of impaired mental health in the respondents who had been unemployed for less than a year were: anxiety $(p<0.03)$, hopelessness $(p<0.001)$, depression $(p<0.004)$, futility $(p<0.001)$. Almost equal results were found in participants unemployed for more than a year, with the addition of a feeling of restlessness $(p<0.009)$ and an increase in the number of days when they feel psychologically ill (11).

The results of ten independent studies have shown a significant protective element of employment for depression. Hopkins Symptom Checklist, Beck Depression Inventory, CES-Depression Scale, Rosenberg's Depression Affect Scale, and Edinburgh Postnatal Depression Scale were used to measure depression. Nine studies examined the impact of unemployment on mental distress using the General Health Ques-

\section{Table 2. Overview of the research included in the review}

\begin{tabular}{|c|c|c|c|c|c|}
\hline $\begin{array}{l}\text { Authors, } \\
\text { year }\end{array}$ & Aim & $\begin{array}{l}\text { Study type / } \\
\text { methodology }\end{array}$ & Population & Country & Results \\
\hline $\begin{array}{l}\text { Driscoll, } \\
\text { Bernstein } \\
\text { (2012.) } \\
\text { [9] }\end{array}$ & $\begin{array}{l}\text { Compare the status } \\
\text { of health insurance, } \\
\text { health and access } \\
\text { to health care } \\
\text { between employed } \\
\text { and unemployed } \\
\text { respondents }\end{array}$ & $\begin{array}{l}\text { Data analysis of } \\
\text { the National Health } \\
\text { Interview Survey } \\
\text { data from } 2009 \\
\text { and } 2010\end{array}$ & $\begin{array}{c}N= \\
\sim 87.500 \\
18-64 \text { y.o. }\end{array}$ & USA & $\begin{array}{l}41.8 \% \text { of the unemployed have health } \\
\text { insurance, as opposed to } 81.4 \% \text { of the } \\
\text { employed adults } \\
\text { The unemployed had poorer physical } \\
\text { and mental health } \\
\text { The unemployed used prescribed } \\
\text { medication to a lesser extent due to } \\
\text { additional expenses }\end{array}$ \\
\hline $\begin{array}{c}\text { Drydakis } \\
\text { (2015.) } \\
\text { [10] }\end{array}$ & $\begin{array}{l}\text { Study the impact } \\
\text { of unemployment } \\
\text { on self-assessed } \\
\text { health and mental } \\
\text { health by comparing } \\
\text { periods at the outset } \\
\text { of the crisis and } \\
\text { after }\end{array}$ & $\begin{array}{l}\text { Longitudinal } \\
\text { Survey 2008-2009 } \\
\text { and 2010-2013. } \\
\text { Results collected } \\
\text { by telephone } \\
\text { interview }\end{array}$ & $n=21.609$ & Greece & $\begin{array}{l}\text { Positive link between unemployment } \\
\text { and poor health } \\
\text { Unemployment due to the closure of } \\
\text { the company additionally adversely } \\
\text { affects the state of health } \\
\text { During } 2010-2013 \text {, unemployment } \\
\text { led to a major deterioration in health } \\
\text { compared to 2008-2009. }\end{array}$ \\
\hline $\begin{array}{l}\text { Noordt et } \\
\text { al. (2014) } \\
\quad[12]\end{array}$ & $\begin{array}{l}\text { Provide a systematic } \\
\text { review of the } \\
\text { literature on the } \\
\text { employment's } \\
\text { effects on health }\end{array}$ & $\begin{array}{l}\text { Systematic } \\
\text { literature review } \\
\text { Search for } \\
\text { prospective studies }\end{array}$ & 33 studies & - & $\begin{array}{l}\text { Employment is a protective factor for } \\
\text { depression and overall mental health } \\
\text { Insufficient evidence found to affect } \\
\text { an individual's overall health }\end{array}$ \\
\hline $\begin{array}{l}\text { Pharr et } \\
\text { al. (2012) } \\
\quad[11]\end{array}$ & $\begin{array}{l}\text { Study the impact of } \\
\text { unemployment on } \\
\text { mental and physical } \\
\text { health, access to } \\
\text { health care, and } \\
\text { health-risk behaviors }\end{array}$ & $\begin{array}{l}\text { Data Analysis: } \\
\text { Nevada } 2009 \\
\text { Behavioral Risk } \\
\text { Factor Surveillance } \\
\text { System }\end{array}$ & $n=3.840$ & $\begin{array}{l}\text { Nevada, } \\
\text { USA }\end{array}$ & $\begin{array}{l}\text { Poorer perception of mental health } \\
\text { in the unemployed, more delayed } \\
\text { seeking health care due to costs, less } \\
\text { likelihood of access to the health } \\
\text { system, unlike the employed }\end{array}$ \\
\hline $\begin{array}{l}\text { Bambra, } \\
\text { Eikemo } \\
(2008) \\
\text { [13] }\end{array}$ & $\begin{array}{l}\text { Identify the } \\
\text { link between } \\
\text { unemployment } \\
\text { and the increased } \\
\text { risk of morbidity } \\
\text { and mortality with } \\
\text { different levels } \\
\text { of protection for } \\
\text { unemployed citizens }\end{array}$ & & $n=37.499$ & EU 23 & $\begin{array}{l}\text { There is a positive correlation } \\
\text { between unemployment and ill health } \\
\text { in all countries } \\
\text { Visible differences in social protection } \\
\text { models: relative differences were } \\
\text { most evident in the Anglo-Saxon, } \\
\text { Bismarck and Scandinavian models. } \\
\text { The negative health effects of } \\
\text { unemployment are particularly visible } \\
\text { in women within the Anglo-Saxon and } \\
\text { Scandinavian models. }\end{array}$ \\
\hline
\end{tabular}


tionnaire Scale, CES-depression Scale and self-created questionnaires. Four of the nine studies cited $(57 \%)$ found a significant protective employment factor for psychological distress, while three studies showed negligible effects (12).

\section{Unemployment and access to health care}

Among the respondents with private health insurance, one in seven (14.7\%) respondents stated that they had delays or lack of medical care due to additional material costs, as opposed to the employed $(8.7 \%)$. In the case of adults with social (state) insurance, one in six (16\%) of the unemployed stated that they had delays or lack of medical care due to additional material costs, unlike the employed (11.2\%). Unemployed respondents were more likely to be delayed or absent from health care than adults with any type of insurance (9).

In the study of Pharr et al. (2012) results indicate that employed respondents were at least 4.1 times more likely to access healthcare than the unemployed respondents. Unemployed participants were at least 2.1 times more likely to delay health care because of the costs they incurred, as opposed to the employed ones (11).

\section{Discussion}

When it comes to unemployment, as one of the important factors in disrupting self-esteem, self-actualization, security and a sense of belonging according to Maslow's hierarchy of needs theory (14), it is difficult to consider unemployment's effect on access to health care services exclusively. It is also important to consider the health of the individual as a final result of the quality of access to the healthcare system due to unemployment, which is at its peak in times of difficult economic situation and global recession.

The psychosocial pressure of the unemployed is particularly emphasized in times of financial crisis as a consequence of the decline in the supply of jobs on the market, which can lead to a period of long-term unemployment resulting in high uncertainty, insecurity, loss of self-esteem and economic struggle for survival (OECD, 2014).
A large number of studies have confirmed that unemployed people are less healthy than employed people, not only in the form of impaired physical but mental health as well $(15,16,17)$. Goldman $(2001)$ and Kawachi and Wamala (2006) observed a significant negative correlation between individual health and unemployment as well as an increase in mortality rates in times of recession. By analyzing data from 23 EU countries, Bambra and Eikemo (2009) find a strong link between unemployment and poor health self-assessment between 2000 and 2002. We can explain the above in several different ways:

1. The negative impact of stress as a direct consequence of unemployment on an individual's health.

2. Difficult access to health care due to loss of health insurance, depending on the model of health insurance of the country in which the individual lives.

3. Changes in lifestyle and eating habits due to reduced income.

4. Absence or termination of preventive health activities.

The lack of material security that job loss brings, according to some authors, leads to a change in lifestyle in terms of increasing unhealthy eating habits and smoking $(18,19,20)$. At the same time, acute and chronic stressors affect the unemployed individual and his or her family as a result of reduced family income (19).

The available data also show that, despite the availability of health insurance, there is no guarantee of better access to health care if the insured person has to contribute to the cost of care (9). In addition to lower levels of health, the unemployed are more likely to delay or not seek health care or medication for an additional cost, unlike employed.

There are a number of factors that will contribute to health outcomes, all of which are simultaneousIy causally linked (Diagram 2). Economic losses at family or individual level caused by recession as a primary factor could secondarily lead to the loss of employment. In addition, gender has been identified as a risk factor, where, according to the ILO, women have a higher unemployment rate than men by $0.4 \%$. The level of social protection of the individual's environment or state is also a potential risk factor. Prior health conditions, such as depression, can sig- 


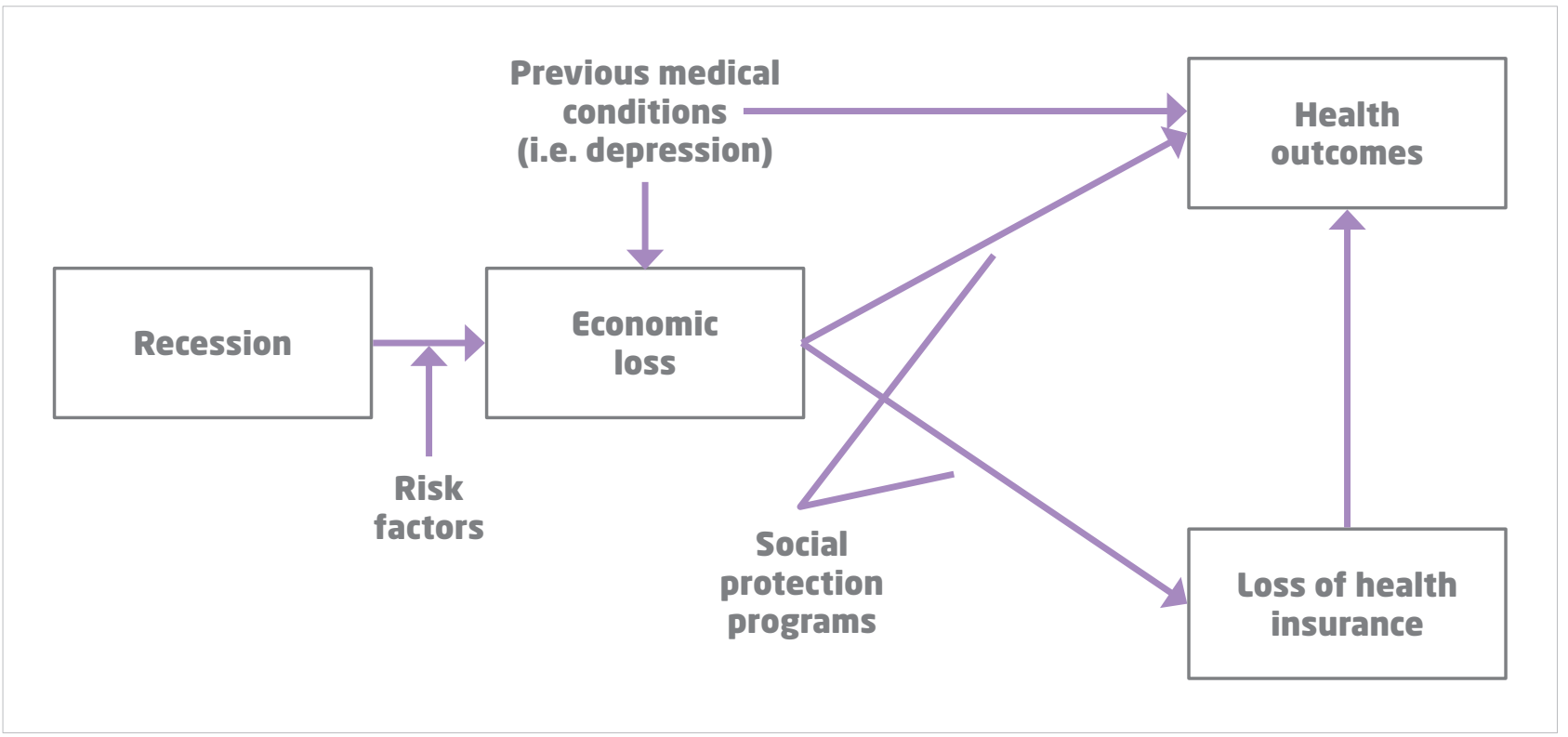

Diagram 2. Impact of recession on health outcomes

nificantly contribute to the economic loss of an individual or family, as well as health outcomes. Either because it will make it easier to lose a job (20) or because the financial burden that certain health condition carries will lead to significant economic losses.

\section{Conclusion}

A considerable number of studies prove that unemployed persons are less healthy than employed, both from the physical and mental aspects of health. The reason for this can be explained by the many negative effects that loss of employment entails, such as the poorer access to the health care system due to inadequate health care for the unemployed and loss of income; less use of the necessary remedies; neglect of preventive health effects due to loss of income or impaired mental state; delaying necessary medical procedures, etc.

Global economic change will have a stronger impact on the health of the population in poor countries than in the rich ones, so a fair and comprehensive system of health care for the unemployed is of paramount importance for the purpose of preserving the health of the population.

\section{References}

1. World Economic Outlook - April 2009: Crisis and Recovery [Internet]. Available from: http://www.imf.org/ external/pubs/ft/weo/2009/01/pdf/text.pdf Accessed: 11.02.2015.

2. World of Work Report 2009. [Internet]. Available from: http://www.ilo.org/wcmsp5/groups/public/---dgreports/--dcomm/documents/publication/wcms_118384.pdf Accessed: 24.02.2015.

3. The Employment Situation: January 2008 [Internet]. U.S. Department of Labor, Bureau of Labor Statistics. Available from: https://www.bls.gov/news.release/archives/empsit_02012008.pdf Accessed: 24.02.2015.

4. Goodman PS. U.S. Unemployment Rate Hits $10.2 \%$, Highest in 26 Years. [Internet]. The New York Times. Available from: https://www.nytimes.com/2009/11/07/ business/economy/07jobs.html Accessed: 05.07.2015.

5. Unemployment rate by sex and age groups - annual average. [Internet]. Eurostat. Available from: http:// appsso.eurostat.ec.europa.eu/nui/submitViewTableAction.do?dvsc $=4$ Accessed: 24.02.2015.

6. Bambra C, Eikemo TA. Welfare state regimes, unemployment and health: a comparative study of the relationship between unemployment and self-reported health in 23 European countries. J Epidemiol Community Health. 2008;63(2):92-8.

7. Katz LF, Meyer BD. The impact of the potential duration of unemployment benefits on the duration of unemployment. J Public Econ. 1990;41(1):45-72. 
8. Molnar A, O'Campo P, Ng E, Mitchell C, Muntaner C, Renahy $E$, et al. Protocol: Realist synthesis of the impact of unemployment insurance policies on poverty and health. Evaluation and Program Planning. 2015;48:1-9.

9. Driscoll $A K$, Bernstein $A B$. Health and access to care among employed and unemployed adults: United States, 2009-2010. NCHS Data Brief. 2012;(83):1-8.

10. Drydakis $\mathrm{N}$. The effect of unemployment on self-reported health and mental health in Greece from 2008 to 2013: A longitudinal study before and during the financial crisis. Soc Sci Med. 2015;128:43-51.

11. Pharr JR, Moonie S, Bungum TJ. The Impact of Unemployment on Mental and Physical Health, Access to Health Care and Health Risk Behaviors. ISRN Public Health. 2012;2012:1-7.

12. Noordt MVD, ljzelenberg $H$, Droomers M, Proper KI. Health effects of employment: a systematic review of prospective studies. Occup Environ Med. 2014;71(10):730-6.

13. Bambra C, Eikemo TA. Welfare state regimes, unemployment and health: a comparative study of the relationship between unemployment and self-reported health in 23 European countries. J Epidemiol Community Health. 2008;63(2):92-8.
14. Maslow hierarchy of needs theory: Employee motivation theories. [Internet]. Maslow hierarchy of needs theory - Employee motivation theories. Available from: http://www.yourcoach.be/en/employee-motivation-theories/maslow-hierarchy-of-needs-theory.php Accessed: 24.02.2015.

15. Kessler RC, Turner JB, House JS. Effects of Unemployment on Health in a Community Survey: Main, Modifying, and Mediating Effects. J Soc Issues. 1988;44(4):69-85.

16. Lahelma, E. Unemployment, re-employment and mental well-being. Scand J Soc Med Suppl. 1989;43:1-170.

17. Paul KI, Moser K. Unemployment impairs mental health: Meta-analyses. J Vocat Behav. 2009;74(3):264-82.

18. Brackbill RM, Siegel PZ, Ackermann SP. Self reported hypertension among unemployed people in the United States. BMJ. 1995;310(6979):568.

19. Laitinen J, Ek E, Sovio U. Stress-Related Eating and Drinking Behavior and Body Mass Index and Predictors of This Behavior. Prev Med. 2002;34(1):29-39.

20. Kawachi I, Wamala S. Globalization and Health: Challenges and Prospects. Glob Health. 2006;3-16. 


\section{NEZAPOSLENOST I PRISTUP ZDRAVSTVENO] ZAŠTITI}

\section{Sažetak}

Uvod. U trenutku oporavka globalne ekonomije od posljedica četvrte velike recesije nakon Drugog svjetskog rata, koja se javila završetkom prve dekade 21. stoljeća - stopa nezaposlenosti posljedično je visoka te predstavlja znatan egzistencijalni i javnozdravstveni izazov.

Cilj. Pružiti sistematični pregled dostupnih istraživanja o utjecaju nezaposlenosti na pristup zdravstvenoj zaštiti, kao i o posljedičnom utjecaju na samo zdravlje pojedinca.

Metode. Provedena je sistematična pretraga elektroničkih znanstvenih baza za sistematične preglede, pregledne članke, originalne istraživačke radove te izvješća u periodu od posljednjih deset godina.

Rezultati. Sistematičnom pretragom recenziranih baza podataka pronađeno je ukupno 10234 članaka, od kojih je pet uključeno u ovaj pregled.

Zaključak. Znatan broj studija dokazuje da su nezaposlene osobe, uslijed ograničenog pristupa zdravstvenoj zaštiti, narušenijeg zdravlja od zaposlenih, kako s fizičkog tako i psihičkog aspekta, što je posljedica negativnih učinaka koje sa sobom nosi gubitak zaposlenja. Globalne ekonomske promjene imat će snažniji utjecaj na zdravlje populacije u siromašnim državama nego u bogatima, stoga je pravedan i sveobuhvatan sustav zdravstvene skrbi za nezaposlene od iznimne važnosti u svrhu očuvanja zdravlja populacije.
Ključne riječi: nezaposlenost, zdravstvena zaštita, ekonomska kriza, recesija 